\title{
Corporate Financial Leverage: A Canada - U.S. Comparison, 1961-1996
}

\author{
by Myles Zyblock*
}

\section{No. 111}

\section{F0019MPE No. 111 \\ ISSN:1200-5223 \\ ISBN: 0-660-17251-8}

Price: $\$ 5.00$ per issue, $\$ 25.00$ annually

\author{
Business and Labour Market Analysis Division \\ 24, R.H. Coats Building, Ottawa, K1A 0T6 \\ *Statistics Canada (613) 951-5132 \\ Facsimile Number: (613) 951-5403
}

\section{December, 1997}

I would like to thank Patrick O'Hagan, Rashmi Shukla, and Garnett Picot for their valuable comments and suggestions throughout the process of this project. Errors remaining are my responsibility.

This paper represents the views of the author and does not necessarily reflect the opinions of Statistics Canada. 



\section{Table of Contents}

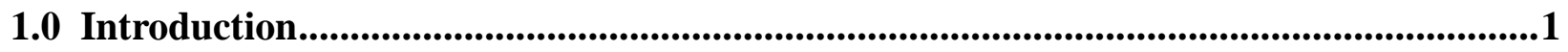

2.0 Sources of Funds for Corporations: Many Factors to Consider ......................................1

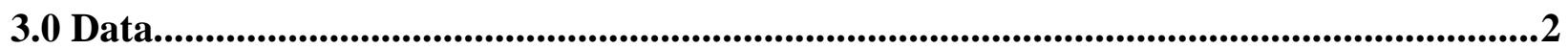

4.0 Corporate Financial Leverage Trends ........................................................................3

4.1 Leverage Trends in Canada ........................................................................................................4

4.2 A Closer Look at Canadian Corporations ..........................................................................................6

4.3 Leverage Trends in the United States ...................................................................................................8

5.0 Concluding Remarks..........................................................................................................11

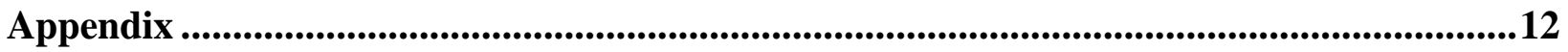

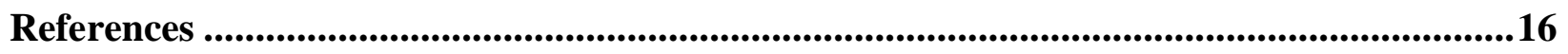





\begin{abstract}
Recent studies have shown that companies with relatively high debt-to-asset (leverage) ratios exhibit more variability in investment and employment patterns. Other studies argue that high aggregate corporate leverage is associated with macroeconomic instability. This paper establishes and compares the evolution of aggregate corporate leverage trends in Canada and the U.S. from 1961 to 1996 . Leverage has increased nearly 50 percent in both countries, and the majority of this increase is attributable to a greater use of short-term debt instruments. Although the magnitude of the increase is similar in both countries, the period harboring the lion's share of the increase is country-specific.

Most of the increase in corporate leverage in Canada occurred between 1974 to 1983; a period associated with low real interest rates and rapid capital expansion in Western Canada. The brunt of the increase in American corporate leverage occurred between 1982 and 1990. Over this period, U.S. companies were in the process of massive capital restructuring by purchasing outstanding equity with borrowed funds. This period was also associated with an increase in the number and value of U.S. leveraged buy-outs that aided in pushing financial leverage higher.
\end{abstract}

Keywords: Corporations, financial leverage, capital structure, debt. 



\subsection{Introduction}

A firm requires financial capital for its operations. The reasons for a firm's choice between different forms of capital such as debt, equity and internally generated funds are complex. These considerations include taxation, market interest rates, inflation expectations and the ability to generate internal funds. Individually and interactively, these factors affect the relative costs between different sources of funds that ultimately determine a firm's capital structure. Although a universal explanation for a firm's choice between different forms of capital is highly desirable, it is likely unobtainable because factors influencing this choice are numerous and dynamic.

Consequences of a firm's capital structure decision have been studied in detail for the United States. American corporations have increased their use of debt as a source of financial capital since the early 1960s (Bernanke, 1993; Masulis, 1988; Davis, 1987; Taggart, 1985). Recent studies have suggested that highly leveraged firms face higher risks of bankruptcy and loan default and display more volatility in their investment and employment patterns. Some reports argue that a highly leveraged corporate sector is responsible for increased macroeconomic instability in the form of deeper recessions and slower recoveries (Sharpe, 1994; Calomiris et al. 1994; Bernanke, 1993; Cantor, 1990; Borio, 1990; Baribeau, 1989; Davis, 1987).

Has Canada's corporate sector demonstrated an increasing propensity to use debt? And, how comparable are these trends in financial leverage to the American experience? The objective of this paper is to outline the financial leverage trends of corporations in Canada and the U.S. from 1961 to 1996, and to offer some plausible explanations for these observed trends. There are no offerings of the economic consequences of changing capital structure; this inquiry should be a valuable part of future research efforts.

\subsection{Sources of Funds for Corporations: Many Factors to Consider}

There are two ways a firm can acquire financial capital for use in its operations: internally, through the use of retained earnings and externally, by borrowing (i.e., issuing debt) or issuing equity. ${ }^{1}$ A corporation's need to obtain external funds is primarily influenced by its financing gap-the difference between capital expenditures and internally generated sources of funds (i.e., retained earnings). However, the choice of instrument used to collect external funds depends on a number of factors. Some factors are briefly highlighted in this section and are not meant to be an exhaustive list. ${ }^{2}$ Rather, they are the determinants repeatedly mentioned in the literature.

\footnotetext{
${ }^{1}$ Firms can also sell existing, and usually non-performing, assets to obtain additional funds. However, this is usually not the preferred method of obtaining funds so it will be excluded from the discussion.

${ }^{2}$ Other reasons for increasing leverage cited in the literature include issues relating to asymmetric information, and the decline in the proportion of bond issues from government (for coverage of these issues see Harris and Raviv, 1991; McDonald, 1983). Although these may be important, we do not discuss them here focusing instead on recurring themes found in most previous literature on this topic.
} 
Theory suggests that the firm's capital structure choice is based on minimizing its weighted average cost of capital (WACC). ${ }^{3}$ There are numerous factors that influence this decision such as taxation. The relative benefit of using debt over share issuance as a source of funds is driven by what is commonly referred to as the interest tax-shield. Interest expenses resulting from servicing debt can be deducted from taxable income, lowering overall expenses and the average cost of capital for the firm. There are several theories used to explain the relative preference for debt over equity financing in the presence of taxation. One such theory suggests that the optimal capital structure of a firm is chosen by equalizing the tax benefits associated with debt and the associated bankruptcy costs as a result of asset liquidation or firm reorganization. Thus, leverage is expected to increase with the corporate tax rate since the benefit of interest deductibility rises.

Inflation, interest rates and expectations about the future evolution of these variables are also important determinants of a firm's choice between debt and equity. Excluding the effects of risk, nominal market interest rates are a function of the real borrowing cost plus an inflation premium. Taking on debt in an inflationary period, especially if the inflation premium embodied in nominal rates does not keep pace with actual price increases, reduces the real cost of debt. On the other hand, financial risk increases when there is an unanticipated decline in inflation. This process, called debt-deflation, raises the burden or value of debt relative to equity and the amount of debt payments relative to cash flow, forcing borrowers to limit their activities. Expectations about the direction of real interest rates can also affect the composition of debt a firm chooses. For example, in periods of low real interest rates a firm needing to use debt will likely find it cheaper to issue longterm debentures if there is an expectation that interest rates will increase.

\subsection{Data}

Values for assets, liabilities and equity are measured on an accounting, or book value, basis. ${ }^{4}$ Aggregate balance sheet items for Canada are obtained from the National Balance Sheet Accounts for non-financial corporations. The non-financial corporate sector is

\footnotetext{
${ }^{3}$ Often referred to as management's hurdle rate, the weighted average cost of capital $\left(\mathrm{r}_{\mathrm{w}}\right)$ is the cash return on assets needed to keep the value of the firm unchanged. It represents the after-tax cost of each element of the capital structure weighted by the percentage of the value of the firm that is comprised of each source of capital (assuming in this case a capital structure comprised of only debt and common equity):

where,

$$
r_{w}=(1-t) r_{d}\left(V_{d} / V_{a}\right)+r_{c e}\left(V_{c e} / V_{a}\right)
$$

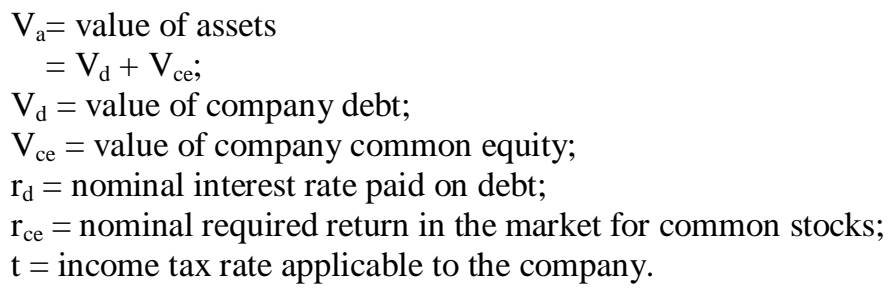

${ }^{4}$ There are three primary ways in which balance sheet values can be measured: Book value, replacement cost, or market value. Each method has its shortcomings and benefits. For a detailed discussion on this topic refer to Taggart (1985), Furstenberg and Malkiel (1977).
} 
comprised of the domestic transactions of private, industrial, Canadian resident corporations. It also includes branches and subsidiaries of foreign corporations operating in Canada. Data used to measure the financing activity of non-financial Canadian corporations are taken from the Financial Flow Accounts. To maintain consistency between corresponding Canadian balance sheet values and U.S. data, non-financial assets are reported using historical cost estimates.

American balance sheet data are obtained from the Balance Sheets for the U.S. economy and the American corporate universe is defined as non-farm, non-financial corporations. The Canadian and American company universes are similar. Financing data for the U.S. are obtained from the Flow of Funds Accounts. All data for the paper has been placed in the Appendix.

Section 4.2 examines industrial level leverage data for twenty-two different non-financial sectors in the Canadian economy from 1980 to 1996; the longest available time series for leverage at this level of aggregation. ${ }^{5}$ Like national data, this data is based on historical cost estimates. Similar comparable data for the U.S. are not available. Definitions of variables constructed from this data are comparable to the definitions embodied in the national data.

\subsection{Corporate Financial Leverage Trends}

The economic landscape of Canada and the U.S. is fairly similar and capital markets are well developed in both countries. Not only are there strong similarities between the two economies, there is an impressive interconnectedness. Recessions and expansions are highly correlated, and economic or financial shocks are transferred across the border at a rapid rate. This interdependence establishes expectations of a strong similarity in the evolution of corporate leverage over time between the two countries. Long-term financial leverage trends are examined for corporations in Canada and the United States from 1961 to 1994 ; the longest available and comparable time series. ${ }^{6}$

Financial leverage is measured by the debt-to-asset ratio (D/A). It is an indicator of the structure of claims on a firm. If the ratio is 0.305 , then one could say that 30.5 percent of the value of assets is 'owed' to creditors. Since assets produce the income required to repay and service a firm's outstanding obligations, an increase in leverage also indicates an increase in the debt burden faced by firms.

\footnotetext{
${ }^{5}$ The industrial classification used is the Standard Industrial Classification for Companies and Enterprises 1980 (SIC-C) which results in a meaningful classification of companies and enterprises that are involved in more than one line of business, or do more than one activity.

${ }^{6}$ Data for the years 1995 and 1996 have been included for Canada.
} 


\subsection{Leverage Trends in Canada}

Figure 1a: Leverage Ratio

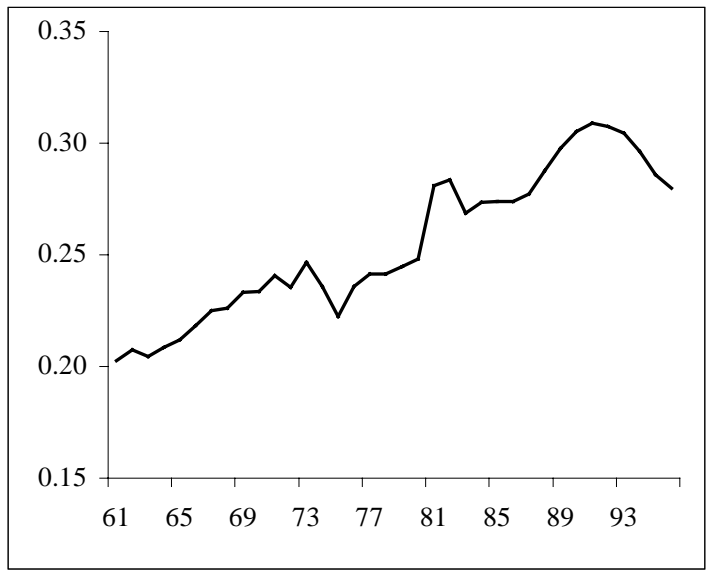

Figure 1b: Leverage Ratio by Component

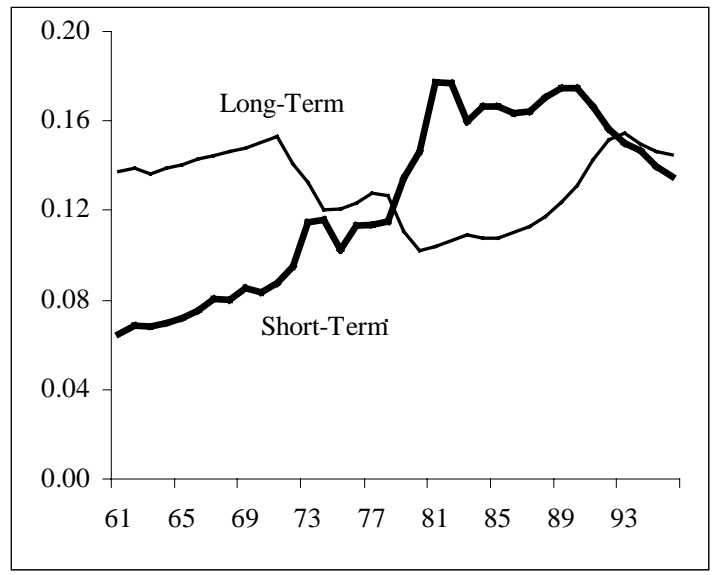

From 1961 to 1994, financial leverage increased 46 percent among Canadian corporations (Figure 1a). This increase was the result of a 126 percent increase in shortterm leverage (Figure 1b). ${ }^{7}$ The period from 1975 to 1982 was characterized by a particularly strong increase in leverage. Over this period, the D/A ratio increased 27 percent and the short-term D/A ratio rose 74 percent. $^{8}$

From the mid-1970s until the early-1980s, some notable events helped to push the aggregate leverage ratio in Canada higher. Companies were rapidly expanding in the West, mainly because of energy production but also because of the buy-outs of foreign firms after the "National Energy Program" was implemented in 1981 (Davis, p.17). Companies chose debt over equity since it was a cheaper form of financing. This may be hard to believe given that 3 month T-bills in Canada were yielding over 20 percent (annualized) and the average yield on Government of Canada long-bonds hovered around 17 percent by mid-1981. But, the answer to this apparent puzzle lies in the development of inflation-adjusted yields. ${ }^{9}$

\footnotetext{
${ }^{7}$ Short-term debt in Canada is defined as the sum on accounts of bank loans, other loans, finance and other short-term paper. Corporate long-term debt for Canada is defined as the sum on the accounts of mortgages and other Canadian bonds. While the splits between short-term and long-term debt are not ideal, they do capture the general duration of the liabilities one would expect in these categories. Moreover, the breakdowns are also consistent with the conventional breakdowns reported in U.S. studies, making crosscountry comparisons more meaningful.

${ }^{8}$ Some of the increase in short-term leverage may be attributable to a misclassification of liabilities.

${ }^{9}$ Inflation-adjusted yields are calculated by subtracting changes in the consumer price index from the average nominal yields of the respective government security for each year in the period. Yields on government of Canada obligations are used instead of corporate yields because they are the benchmark from which all yield curves are derived.
} 
Figure 2a: Inflation-Adjusted Yields

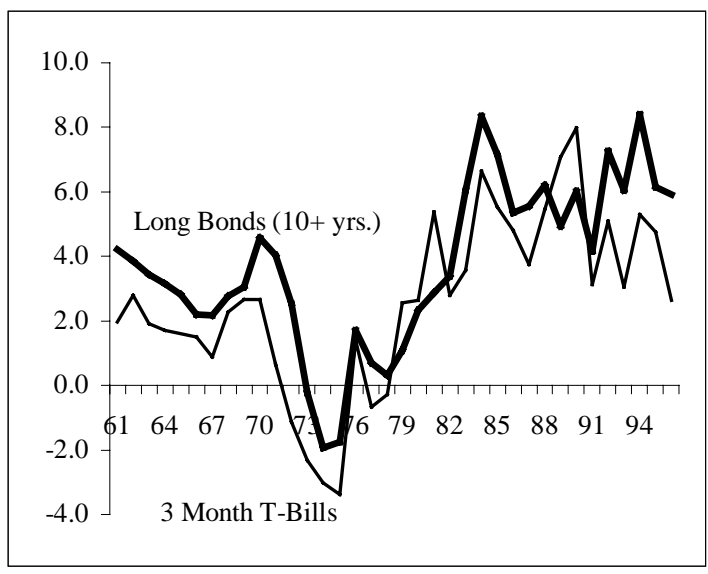

Figure 2b: \% Change in the CPI

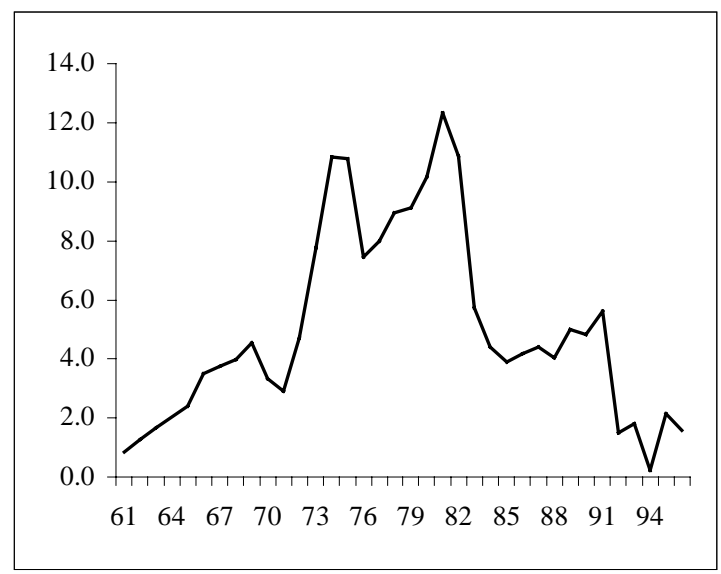

Over a large part of the 1970s, inflation-adjusted interest rates were very low, and in some years they were negative (Figure 2a). This meant that the real cost of borrowing was extremely low. Thus, it is not entirely surprising that issuing debt was the preferred method of financing.

As long as actual inflation exceeds the inflation premium embodied in nominal interest rates, the real cost of borrowing declines. However, if there is an unexpected decline in inflation the burden of debt increases. In the early 1980s, inflation declined markedly, and the burden of outstanding debt increased significantly (Figure 2b). This process, referred to as debt-deflation, forced many corporations to limit their economic activities. The impact of debt-deflation on corporate financial security was severe; the rate of default and business failures peaked in 1981 (Davis p.67).

Figure 3: External Sources of Funds and Financing Gap

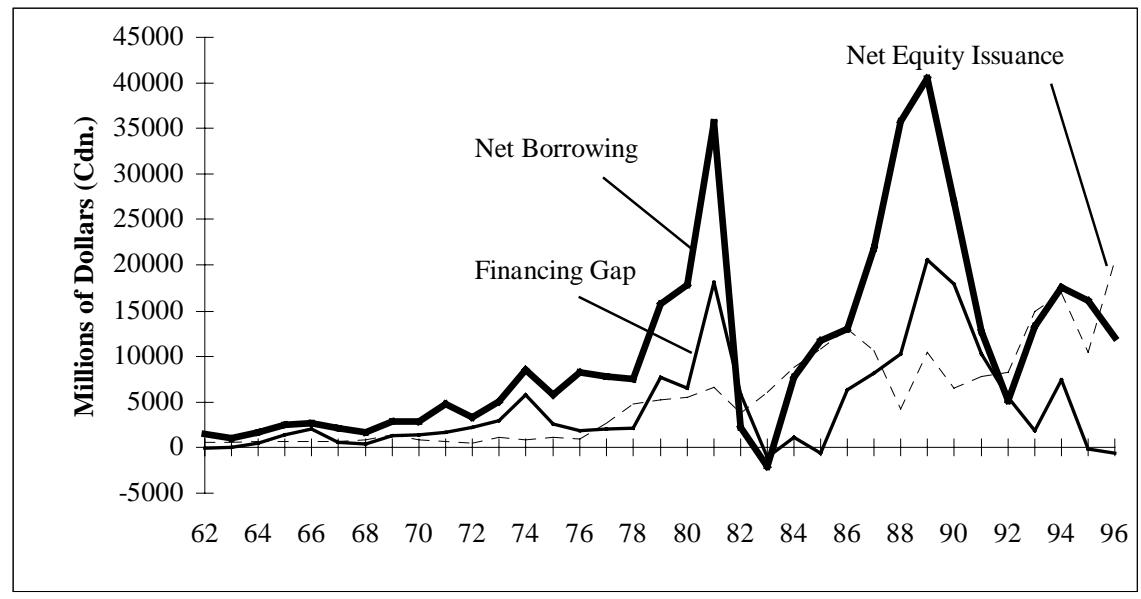

From 1983 to 1989 , D/A increased 11 percent. This relatively small increase is somewhat surprising given the robust economic activity over the period. It is most likely attributable to a combination of three factors. First, the real cost of debt was rising and was relatively higher than earlier periods (Figure 2a). Second, if corporations were to avoid a situation 
of debt-overhang similar to that experienced in the early 1980s, maintaining leverage growth would be important. Third, a rising number of corporations were enticed to finance a growing portion of their external capital requirements with equity in response to a bull-market for stocks that started in the early 1980s. In combination, these factors produced a noticeable shift in financing to equity capital (Figure 3).

The sharp decline in leverage that started in the late 1980s (Figure 1a) was in response to the slowdown in growth that culminated into an early 1990s recession. However, even as growth started to pick up, corporate leverage declined further. The continued resistance to lever corporate balance sheets is apparently being influenced by the persistence of the stock market boom, and memories of previous recessions.

Borrowing among Canadian corporations is closely associated with the financing gap (Figure 3) over the entire period. ${ }^{10}$ This indicates that corporations have been using external funds to purchase capital that produces the income needed to repay the associated obligations, rather than to refinance existing obligations or purchase outstanding equity.

Behind the scenes, Canadian corporate tax policy since 1961 was having a positive effect on leverage. Because interest expenses are deductible from taxable income, corporations were provided with an incentive to issue debt (Bartholdy et al., 1989; Shum, 1996). ${ }^{11}$

\subsection{A Closer Look at Canadian Corporations}

One argument against assessing the direction or importance of corporate leverage trends with aggregate data is that the data can conceal events occurring within particular industries. Is the direction of aggregate leverage trends the result of increasing leverage across many industries, or due to a sharp increase in one very large industry? Moreover, if the increase in leverage is a general phenomenon, one is justified in forwarding macroeconomic explanations for this increase.

Intra-period leverage trends within particular industries are broadly consistent with aggregate leverage trends reported earlier (Table 1). From 1980 to 1990, a period of increasing aggregate leverage, fifteen of twenty-two industries also increased leverage. Seventeen of twenty-two industries reduced leverage from 1990 to 1996; a period of declining aggregate corporate leverage.

\footnotetext{
${ }^{10}$ The association between the financing gap and net new borrowing is not nearly as strong in the U.S. This is highlighted in a subsequent section.

${ }^{11}$ The expected positive relationship between corporate taxes and leverage has not found much support in America (e.g., Chaplinsky and Niehaus, 1993; Titman and Wessels, 1988). This is likely due to the complex interactions between personal and corporate taxes that differ from those experienced in Canada.
} 
Table 1: Percentage Change in Leverage (D/A): 22 Canadian Industries

\section{Industry:}

Accomodation, Food and Beverage, Educational, Health and Recreational Services

Beverages and Tobacco

Building Materials and Construction

Chemicals, Chemical Products and Textiles

Consumer Goods and Services

Electronic Equipment and Computer Services

Fabricated Metal Products

Food (including food retailing)

**General Services to Business

**Household Appliances and Electrical Products Iron, Steel and Related Products

**Machinery and Equipment (except electrical machinery)

Motor Vehicle Parts \& Accessories

Non-ferrous Metals and Primary Metal Products

Other Fuels and Electricity

**Other Transportation Equipment

Petroleum and Natural Gas

**Printing, Publishing and Broadcasting

**Real Estate Developers, Builders and Operators

**Telecommunications Carriers and Postal

and Courier Services

**Transportation Services

**Wood and Paper

\begin{tabular}{|c|c|c|c|c|}
\hline $1980-90$ & $1990-96$ & 1980-1996 & \begin{tabular}{|l|} 
Industry Assets \\
as a \% of Total
\end{tabular} & $\begin{array}{r}\text { Size } \\
\text { Rank } \\
\end{array}$ \\
\hline 5.9 & 1.3 & 7.3 & $6.20 \%$ & 5 \\
\hline 14.7 & -37.2 & -28.0 & $1.91 \%$ & 18 \\
\hline 73.1 & 8.8 & 88.4 & $2.89 \%$ & 16 \\
\hline-20.4 & -30.4 & -44.5 & $5.07 \%$ & 8 \\
\hline 26.5 & -23.2 & -2.9 & $6.12 \%$ & 6 \\
\hline-19.9 & -11.7 & -29.3 & $3.00 \%$ & 15 \\
\hline 29.8 & -9.8 & 17.2 & $2.05 \%$ & 17 \\
\hline-1.0 & -18.1 & -19.0 & $3.63 \%$ & 11 \\
\hline 23.7 & -13.0 & 7.7 & $3.47 \%$ & 13 \\
\hline 27.7 & 7.0 & 36.7 & $1.08 \%$ & 21 \\
\hline 45.3 & -20.5 & 15.5 & $1.55 \%$ & 19 \\
\hline-16.6 & -20.5 & -33.8 & $3.02 \%$ & 14 \\
\hline 54.3 & -32.0 & 4.9 & $6.85 \%$ & 3 \\
\hline-5.1 & 9.5 & 3.9 & $5.51 \%$ & 7 \\
\hline 52.6 & 6.4 & 62.5 & $1.53 \%$ & 20 \\
\hline 34.8 & -3.0 & 30.7 & $1.06 \%$ & 22 \\
\hline 12.6 & -7.0 & 4.7 & $14.26 \%$ & 1 \\
\hline 11.8 & -2.1 & 9.5 & $4.12 \%$ & 10 \\
\hline-23.1 & -7.0 & -28.5 & $12.03 \%$ & 2 \\
\hline-17.6 & -2.8 & -19.9 & $3.58 \%$ & 12 \\
\hline 15.9 & -14.0 & -0.2 & $4.38 \%$ & 9 \\
\hline 33.8 & -8.3 & 22.7 & $6.71 \%$ & 4 \\
\hline 23.0 & -8.2 & 12.9 & $100 \%$ & \\
\hline 15 increased & 5 increased & 13 increased & & \\
\hline 6 decreased & 17 decreased & 8 decreased & & \\
\hline 1 no change & 0 no change & 1 no change & & \\
\hline
\end{tabular}

*A change of less than or equal to 1 percent (absolute value) is considered no change.
**Average leverage of industry for the period exceeds aggregate average leverage.

All non-financial Industries

Total increases/decreases, by Industry*

The Wood and Paper industry played a large role in pushing up aggregate leverage since 1980 (Table 1). Not only is this industry relatively large according to asset size, but it also increased leverage at a rate greater than the average. Moreover, this industry has a leverage ratio exceeding the aggregate leverage ratio.

At least for the period from 1980 to 1996, increasing corporate leverage was a general corporate phenomenon. Reversals in leverage trends within industries over the period are broadly consistent with the leverage dynamics shown in economy-wide data. However, one large industry appears to be playing a disproportionate role in increasing corporate leverage: Wood and Paper. 


\subsection{Leverage Trends in the United States}

Figure 4a: Leverage Ratio

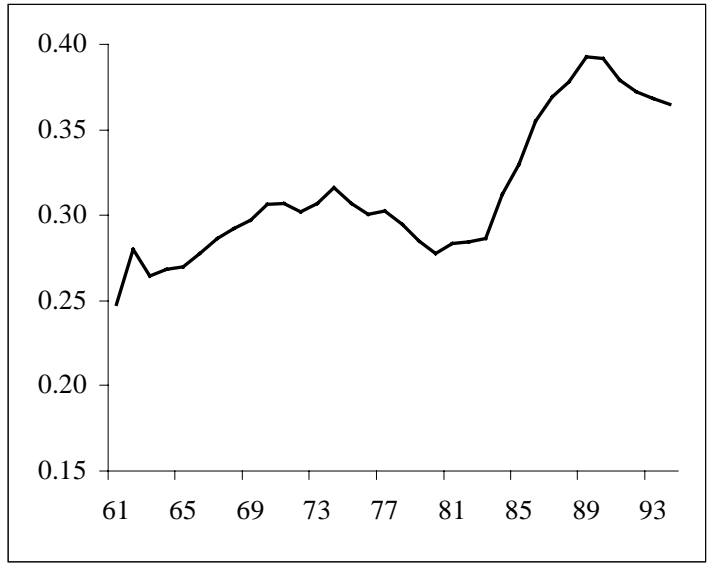

Figure 4b: Leverage Ratio by Component

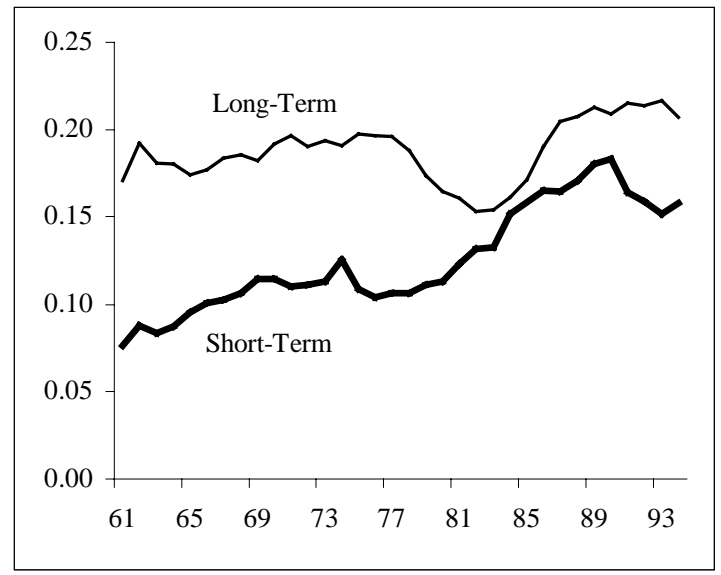

U.S. corporations increased leverage by 48 percent from 1961 to 1994 (Figure 4a); an increase very similar in magnitude to that seen among Canadian corporations. Also, the increase in total leverage was largely the response to a 108 percent increase in short-term leverage (Figure $4 \mathrm{~b}$ ). ${ }^{12}$ Unlike the large increase in Canada from the mid-1970s to early 1980s, leverage among U.S. corporations rose 7 percent over the same period. This is somewhat surprising given that inflation and market interest rates followed strikingly similar paths in the two countries. ${ }^{13}$

Increasing leverage in the U.S. was a appreciable event of the 1980s. From 1983 to 1989, leverage increased 37 percent with contributions coming from short- and long-term leverage (Figure $4 b)$.

Figure 5: Incidence of Merger and Acquisition Activity (1979=100)

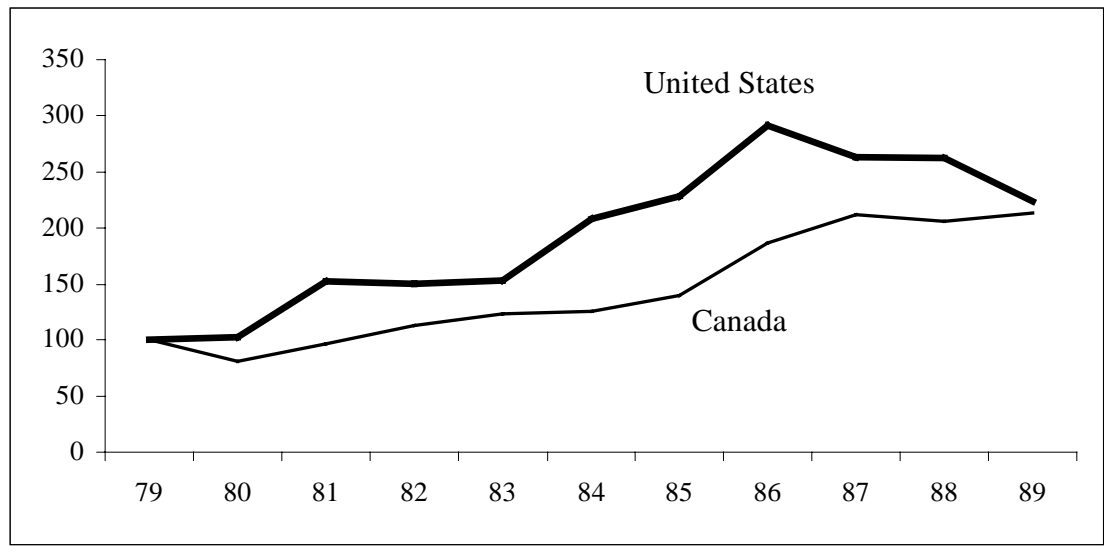

\footnotetext{
${ }^{12}$ Short-term debt in the U.S. is defined as bank loans (not elsewhere classified), commercial paper, and other loans. Long-term debt is defined as tax-exempt debt, corporate bonds and mortgages. These classifications are meant to be consistent with the classifications used for Canada. However, some of the increase in short-term leverage may be due to inexact categorizations.

${ }^{13}$ See data in Appendix, A.3.
} 
There are two primary reasons for the considerable use of debt over the 1980s: growth in merger and acquisition activity ${ }^{14}$, and a large capital restructuring.

Company mergers and acquisitions (M\&As) usually occur because owners believe the value of the combined company exceeds the sum of the value of the two companies independently. From 1983 to 1988, M\&A activity increased 68 percent in Canada and 71 percent in the U.S. (Figure 5).

A merger or acquisition does not necessarily lead to an increase in the leverage of the resultant company since M\&As can be financed by any combination of cash, debt, or equity. However, one particular form of M\&A activity that increases leverage is the leveraged buy-out (LBO). ${ }^{15}$ These types of highly leveraged transactions often result in debt-to-asset ratios ranging from 80 to 95 percent upon completion of the deal (Borio, p.38). Between 1982 and 1988, the value of M\&As in the U.S. increased from 6 percent to about 20 percent of GNP (Borio, p.35). Moreover, the share of M\&A activity which took the form of a LBO rose from about 5 percent to 20 percent over the same period.

Highly leveraged transactions have been rare in Canada probably because of the relatively high degree of concentration of ownership and control. This decreases the likelihood of hostile operations by outsiders because it diminishes the potential for gains from these transactions.

A growing spread has developed between net new debt issuance and the financing gap among American corporations since the mid-1970s (Figure 6). It was not until the early 1980s that there was a marked break in the financing patterns of U.S. corporations. From 1983 to 1990, the net borrowing pattern was essentially a mirror image of the net equity issuance pattern as corporations became heavily involved in debt-for-equity swaps

\footnotetext{
${ }^{14}$ The data for Figure 5 were taken from two studies. Data from 1979 to 1986 are from Marfel (1988) and for the remainder of the period the data are borrowed from Khemani (1991). Both studies use the same primary data source.

${ }^{15}$ A leveraged buy-out is a highly debt financed acquisition through which a company is often taken private.
} 
Figure 6: External Sources of Funds and Financing Gap

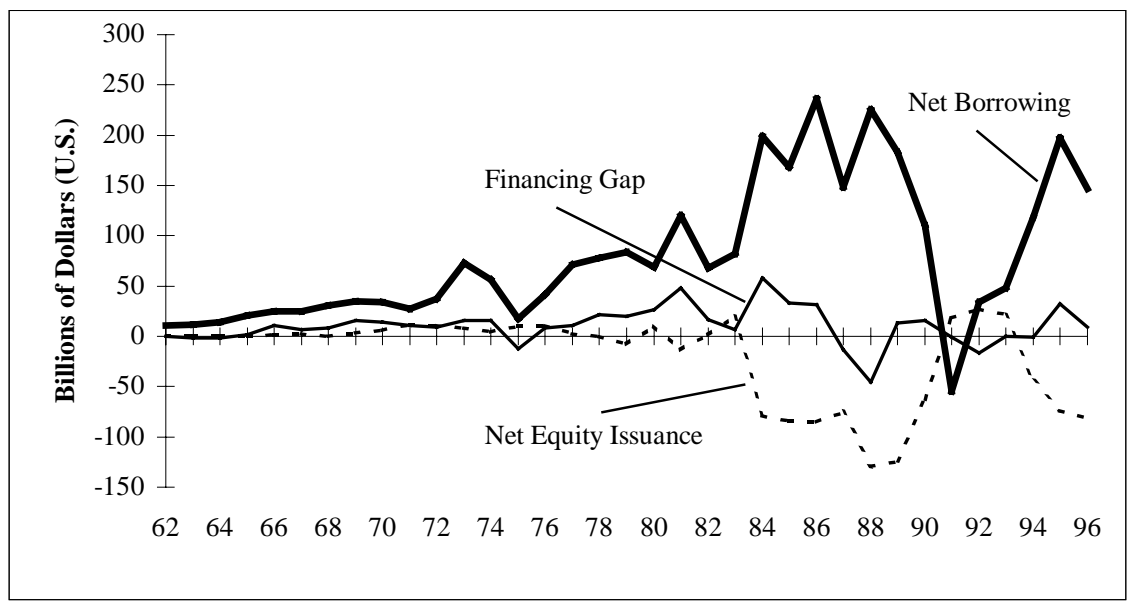

(i.e. the purchase of outstanding equity with borrowed funds). This form of capital restructuring helped push aggregate corporate leverage in America higher. Generally, this activity involves more risk than the financing approach undertaken by Canadian companies because U.S. companies borrowed to purchase assets producing no income to pay for the associated obligations. Capital structure choices made by American corporations have been unresponsive to the U.S. stock market boom that began in the early 1980 s.

So American corporations left the 1980s with a large amount of debt on their balance sheets because of the increased frequency and size of LBOs, and the debt-for-equity swaps. This left corporations with debt-overhang as aggregate demand decreased in the early 1990s. Many studies have argued that the early 1990s U.S. recession was more severe for firms and the accompanying expansion relatively weaker than its early 1980s predecessor because of the high degree of leverage carried on corporate balance sheets. Defaults on corporate loans in 1991 were double what they had been in the 1980s recession (Remolana, et al., 1993); the 1990s recessions was accompanied by an unusually early decline in employment and inventories (Bernanke, 1993); and, there was an unusually slow recovery after the initial 1990s recessionary stimuli had passed (Bernanke, 1993).

Since the most recent recession, American corporations have been reducing leverage (Figure 4a). This may have been in response to the hardships highly leveraged corporations felt in the early 1990s. Or, it may be the result of a compositional change; that the most highly leveraged firms did not survive the decline in aggregate demand, leaving behind only those corporations with relatively clean balance sheets to continue. 


\subsection{Concluding Remarks}

The economic landscape in Canada and the U.S. has been very similar since 1961 . Inflation, market interest and economic growth have followed the same general patterns, the financial and policy infra-structure have developed similarly and yet, corporate balance sheets have evolved differently and for quite different reasons.

Financial leverage of Canadian and American corporations increased similarly in magnitude from 1961 to 1994. The largest increases in leverage among Canadian corporations took place from 1975 to 1982 . This increase is primarily attributable to two factors: rapid expansion in Western Canada which was financed primarily with debt; and, low and sometimes negative inflation-adjusted interest rates over a large part of the latter1970s creating favourable conditions for debt financing. Reversals in aggregate corporate leverage trends in Canada correspond closely with industry leverage patterns. Changes in corporate leverage appear to be influenced by macroeconomic events rather than being solely determined by microeconomic factors.

On the other hand, corporate leverage in America rose sharply from 1983 to 1989. Over this period, corporations were undertaking a major capital restructuring initiative by purchasing outstanding equity with debt. Around the same time, highly leveraged transactions in the form of leveraged buy-outs increased in number and total value pushing aggregate corporate leverage to higher levels.

In both countries, the rise in corporate leverage is attributable to an increase in the use of short-term debt-instruments. This represents an increasing likelihood of a mismatch between the duration of assets and liabilities, raising the overall level of financial risk embodied in corporate balance sheets. However, a more detailed study on the duration of assets will be needed to establish the magnitude of this risk.

According to recent studies about financial leverage, the 1980s recession in Canada was particularly severe for firms in terms of its depth and the number of business failures (Davis, 1987). Similarly, the early 1990s U.S. recession for the corporate sector has been referred to as being unusually deep with the accompanying recovery being atypically slow (Sharpe, 1994; Bernanke, 1993; Remolana et al., 1993). This naturally leads one to speculate about the importance of corporate leverage for economic stability.

It is difficult to determine from the aggregate data presented in this paper if the level of leverage carried by firms in either country is presently too high in the face of another cyclical downturn. Decreasing debt-use over the 1990s by corporations in both countries may be a signal of confirmation for this idea. However, to more fully appreciate the relationship between leverage and investment or employment one needs to explore firmlevel data. This data would need to link the financial and real sides of a corporation over time. Presently, a representative corporate longitudinal firm-level sample is unavailable for Canada. 


\section{Appendix}

A.1 Aggregate Balance Sheet Data*

\begin{tabular}{|c|c|c|c|c|c|c|c|c|c|c|c|c|}
\hline \multicolumn{2}{|r|}{ Canada: } & & & & & & \multicolumn{6}{|c|}{ United States: } \\
\hline & Assets & $\begin{array}{c}\text { Short-term } \\
\text { Debt }\end{array}$ & $\begin{array}{l}\text { Long-term } \\
\text { Debt }\end{array}$ & $\begin{array}{c}\text { Total } \\
\text { Leverage }\end{array}$ & $\begin{array}{l}\text { Short-Term } \\
\text { Leverage }\end{array}$ & $\begin{array}{l}\text { Long-term } \\
\text { Leverage }\end{array}$ & Assets & $\begin{array}{c}\text { Short-term } \\
\text { Debt }\end{array}$ & $\begin{array}{l}\text { Long-term } \\
\text { Debt }\end{array}$ & $\begin{array}{c}\text { Total } \\
\text { Leverage }\end{array}$ & $\begin{array}{c}\text { Short-Term } \\
\text { Leverage }\end{array}$ & $\begin{array}{l}\text { Long-term } \\
\text { Leverage }\end{array}$ \\
\hline 1961 & 66755.0 & 4346.0 & 9175.0 & 0.203 & 0.065 & 0.137 & 628.0 & 48.0 & 107.3 & 0.247 & 0.076 & 0.171 \\
\hline 1962 & 70730.0 & 4853.0 & 9830.0 & 0.208 & 0.069 & 0.139 & 592.5 & 52.1 & 113.9 & 0.280 & 0.088 & 0.192 \\
\hline 1963 & 75893.0 & 5186.0 & 10345.0 & 0.205 & 0.068 & 0.136 & 669.1 & 56.1 & 120.9 & 0.265 & 0.084 & 0.181 \\
\hline 1964 & 81307.0 & 5674.0 & 11279.0 & 0.209 & 0.070 & 0.139 & 712.2 & 62.4 & 128.5 & 0.268 & 0.088 & 0.180 \\
\hline 1965 & 90683.0 & 6515.0 & 12711.0 & 0.212 & 0.072 & 0.140 & 783.1 & 74.9 & 136.4 & 0.270 & 0.096 & 0.174 \\
\hline 1966 & 101281.0 & 7646.0 & 14473.0 & 0.218 & 0.075 & 0.143 & 849.3 & 85.6 & 150.4 & 0.278 & 0.101 & 0.177 \\
\hline 1967 & 110224.0 & 8879.0 & 15925.0 & 0.225 & 0.081 & 0.144 & 911.4 & 93.6 & 167.1 & 0.286 & 0.103 & 0.183 \\
\hline 1968 & 117428.0 & 9408.0 & 17160.0 & 0.226 & 0.080 & 0.146 & 994.1 & 106.1 & 184.4 & 0.292 & 0.107 & 0.185 \\
\hline 1969 & 129376.0 & 11052.0 & 19113.0 & 0.233 & 0.085 & 0.148 & 1093.3 & 125.6 & 199.3 & 0.297 & 0.115 & 0.182 \\
\hline 1970 & 142770.0 & 11909.0 & 21465.0 & 0.234 & 0.083 & 0.150 & 1162.9 & 133.5 & 223.0 & 0.307 & 0.115 & 0.192 \\
\hline 1971 & 156950.0 & 13761.0 & 24022.0 & 0.241 & 0.088 & 0.153 & 1251.9 & 138.0 & 246.0 & 0.307 & 0.110 & 0.197 \\
\hline 1972 & 173476.0 & 16428.0 & 24404.0 & 0.235 & 0.095 & 0.141 & 1392.9 & 155.2 & 265.3 & 0.302 & 0.111 & 0.190 \\
\hline 1973 & 203572.0 & 23307.0 & 26932.0 & 0.247 & 0.114 & 0.132 & 1572.9 & 178.5 & 304.2 & 0.307 & 0.113 & 0.193 \\
\hline 1974 & 253222.0 & 29310.0 & 30386.0 & 0.236 & 0.116 & 0.120 & 1701.5 & 213.1 & 324.9 & 0.316 & 0.125 & 0.191 \\
\hline 1975 & 287827.0 & 29375.0 & 34680.0 & 0.223 & 0.102 & 0.120 & 1814.4 & 197.9 & 358.6 & 0.307 & 0.109 & 0.198 \\
\hline 1976 & 317272.0 & 35834.0 & 39013.0 & 0.236 & 0.113 & 0.123 & 1978.6 & 205.9 & 388.4 & 0.300 & 0.104 & 0.196 \\
\hline 1977 & 352277.0 & 40011.0 & 44972.0 & 0.241 & 0.114 & 0.128 & 2201.9 & 234.7 & 431.1 & 0.302 & 0.107 & 0.196 \\
\hline 1978 & 396370.0 & 45551.0 & 50202.0 & 0.242 & 0.115 & 0.127 & 2506.4 & 267.2 & 471.2 & 0.295 & 0.107 & 0.188 \\
\hline 1979 & 468864.0 & 62923.0 & 51759.0 & 0.245 & 0.134 & 0.110 & 2881.7 & 321.2 & 499.4 & 0.285 & 0.111 & 0.173 \\
\hline 1980 & 539428.0 & 78993.0 & 54863.0 & 0.248 & 0.146 & 0.102 & 3188.3 & 360.6 & 525.0 & 0.278 & 0.113 & 0.165 \\
\hline 1981 & 631342.0 & 112001.0 & 65471.0 & 0.281 & 0.177 & 0.104 & 3524.3 & 432.7 & 565.9 & 0.283 & 0.123 & 0.161 \\
\hline 1982 & 669204.0 & 118401.0 & 71261.0 & 0.283 & 0.177 & 0.106 & 3735.5 & 491.6 & 571.9 & 0.285 & 0.132 & 0.153 \\
\hline 1983 & 689270.0 & 110039.0 & 75171.0 & 0.269 & 0.160 & 0.109 & 4076.6 & 539.5 & 628.0 & 0.286 & 0.132 & 0.154 \\
\hline 1984 & 743808.0 & 123653.0 & 79856.0 & 0.274 & 0.166 & 0.107 & 4380.5 & 663.9 & 705.0 & 0.312 & 0.152 & 0.161 \\
\hline 1985 & 789014.0 & 131312.0 & 84887.0 & 0.274 & 0.166 & 0.108 & 4679.3 & 740.8 & 801.7 & 0.330 & 0.158 & 0.171 \\
\hline 1986 & 833590.0 & 136317.0 & 91888.0 & 0.274 & 0.164 & 0.110 & 4995.9 & 822.8 & 951.3 & 0.355 & 0.165 & 0.190 \\
\hline 1987 & 896169.0 & 147223.0 & 101103.0 & 0.277 & 0.164 & 0.113 & 5336.7 & 878.2 & 1091.7 & 0.369 & 0.165 & 0.205 \\
\hline 1988 & 978763.0 & 167060.0 & 114534.0 & 0.288 & 0.171 & 0.117 & 5735.8 & 979.8 & 1189.1 & 0.378 & 0.171 & 0.207 \\
\hline 1989 & 1067323.0 & 186256.0 & 131708.0 & 0.298 & 0.175 & 0.123 & 6023.8 & 1085.1 & 1280.5 & 0.393 & 0.180 & 0.213 \\
\hline 1990 & 1114456.0 & 194483.0 & 145851.0 & 0.305 & 0.175 & 0.131 & 6304.9 & 1153.6 & 1315.8 & 0.392 & 0.183 & 0.209 \\
\hline 1991 & 1127045.0 & 187525.0 & 160561.0 & 0.309 & 0.166 & 0.142 & 6483.9 & 1064.0 & 1394.0 & 0.379 & 0.164 & 0.215 \\
\hline 1992 & 1151457.0 & 179820.0 & 174299.0 & 0.308 & 0.156 & 0.151 & 6717.9 & 1066.5 & 1434.0 & 0.372 & 0.159 & 0.213 \\
\hline 1993 & 1202068.0 & 180451.0 & 185681.0 & 0.305 & 0.150 & 0.154 & 6954.0 & 1053.4 & 1507.2 & 0.368 & 0.151 & 0.217 \\
\hline 1994 & 1293358.0 & 189815.0 & 193458.0 & 0.296 & 0.147 & 0.150 & 7351.1 & 1159.2 & 1521.6 & 0.365 & 0.158 & 0.207 \\
\hline 1995 & 1393386.0 & 194447.0 & 203571.0 & 0.286 & 0.140 & 0.146 & N/A & N/A & N/A & N/A & N/A & N/A \\
\hline 1996 & 1455433.0 & 196640.0 & 210834.0 & 0.280 & 0.135 & 0.145 & N/A & N/A & N/A & N/A & N/A & N/A \\
\hline
\end{tabular}

* Assets and liabilities are reported in \$Millions for Canada and \$Billions for the U.S., each in their respective currencies. 


\section{A.2 Aggregate Financial Flow Data*}

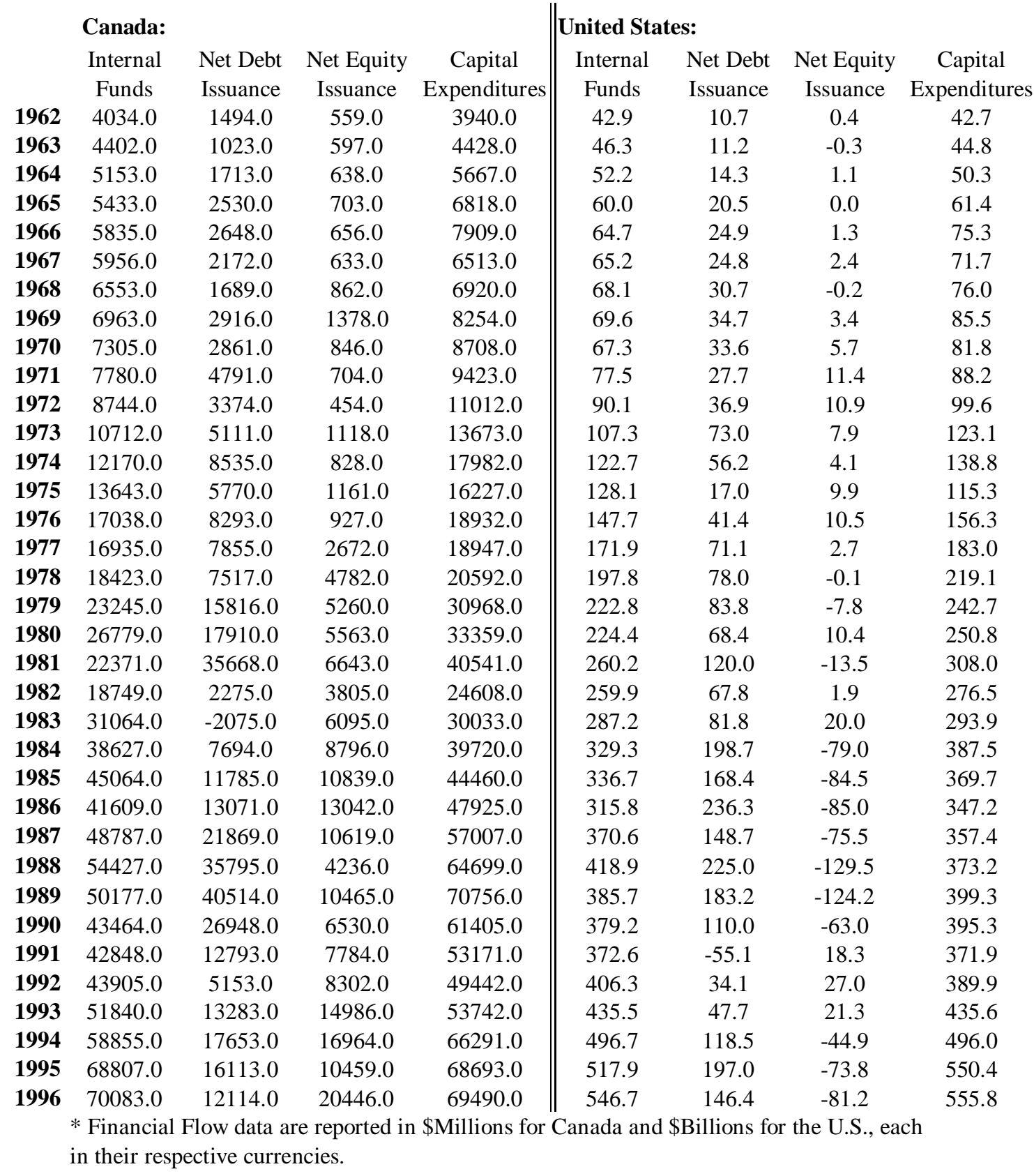

Analytical Studies Branch - Research Paper Series - 13 - $\quad$ Statistics Canada No. 11F0019MPE No. 111 


\section{A.3 Inflation and Interest Rate Data*}

\section{Canada:}

Nominal 3-Month Nominal 10+ Yr. \% Change in Treasury Yields Govt. Bond Yields

$$
\begin{aligned}
& 1961 \\
& 1962 \\
& 1963 \\
& 1964 \\
& 1965 \\
& 1966
\end{aligned}
$$

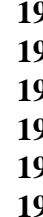$$
1967
$$$$
1968
$$

$$
1969
$$

\section{7}

\section{1}

1973

$$
1974
$$

\section{5}

\section{6}$$
1978
$$

$$
1979
$$

$$
198
$$

\section{8}

$$
198
$$$$
198
$$

\section{5}

1986$$
1987
$$$$
198
$$

$$
199
$$

$$
1991
$$$$
1992
$$

1993

1994

1995

1996
United States:

Nominal 3-Month Nominal 10+ Yr. \% Change in Treasury Yields Govt. Bond Yields CPI $\begin{array}{lll}2.38 & 3.90 & 1.0 \\ 2.78 & 3.95 & 1.3\end{array}$ $\begin{array}{lll}3.16 & 4.00 & 1.3\end{array}$ $\begin{array}{lll}3.55 & 4.15 & 1.3\end{array}$ $\begin{array}{lll}3.95 & 4.21 & 1.6\end{array}$ $\begin{array}{lll}4.88 & 4.65 & 2.9\end{array}$ $\begin{array}{lll}4.33 & 4.85 & 3.1\end{array}$ $\begin{array}{lll}5.35 & 5.26 & 4.2\end{array}$ $\begin{array}{lll}6.69 & 6.12 & 5.5\end{array}$ $\begin{array}{lll}6.44 & 6.58 & 5.7\end{array}$ $\begin{array}{lll}4.34 & 5.74 & 4.4\end{array}$ $\begin{array}{lll}4.07 & 5.63 & 3.2\end{array}$ $\begin{array}{lll}7.02 & 6.30 & 6.2\end{array}$ $\begin{array}{lll}7.87 & 6.98 & 11.0\end{array}$ $\begin{array}{lll}5.82 & 6.98 & 9.1\end{array}$ $\begin{array}{lll}5.00 & 6.78 & 5.8\end{array}$ $\begin{array}{lll}5.27 & 7.06 & 6.5\end{array}$ $\begin{array}{lll}7.22 & 7.89 & 7.6\end{array}$ $\begin{array}{lll}10.04 & 8.74 & 11.3\end{array}$ $\begin{array}{lll}11.61 & 10.81 & 13.5\end{array}$ $\begin{array}{lll}14.08 & 12.87 & 10.3\end{array}$ $\begin{array}{lll}10.89 & 12.23 & 6.2\end{array}$ $\begin{array}{lll}8.62 & 10.84 & 3.2\end{array}$ $\begin{array}{lll}9.57 & 11.99 & 4.2\end{array}$ $\begin{array}{lll}7.49 & 10.75 & 3.7\end{array}$ $\begin{array}{lll}5.97 & 8.14 & 2.0\end{array}$ $\begin{array}{lll}5.83 & 8.63 & 3.6\end{array}$ $\begin{array}{lll}6.67 & 8.98 & 4.1\end{array}$ $\begin{array}{lll}8.12 & 8.59 & 4.7\end{array}$ $\begin{array}{lll}7.51 & 8.73 & 5.3\end{array}$ $\begin{array}{lll}5.41 & 8.16 & 4.2\end{array}$ $\begin{array}{lll}3.46 & 7.52 & 3.0\end{array}$ $\begin{array}{lll}3.02 & 6.46 & 2.9\end{array}$ $\begin{array}{lll}4.27 & 7.41 & 2.6\end{array}$ $\begin{array}{lll}5.51 & 6.94 & 2.8\end{array}$ $5.02 \quad 6.80 \quad 3.0$ * Yields are calculated based on average annual yields. Yield data are from the Bank of Canada and CPI data are derived from Cansim. 


\section{A.4 Incidence of Mergers and Acquisitions*}

$\begin{array}{ccc} & \text { Canada } & \text { U.S. } \\ 1970 & 427 & 1318 \\ 1971 & 388 & 1269 \\ 1972 & 429 & 1263 \\ 1973 & 352 & 1064 \\ 1974 & 296 & 926 \\ 1975 & 264 & 981 \\ 1976 & 313 & 1145 \\ 1977 & 395 & 1209 \\ 1978 & 449 & 1452 \\ 1979 & 511 & 1526 \\ 1980 & 414 & 1565 \\ 1981 & 491 & 2326 \\ 1982 & 576 & 2295 \\ 1983 & 628 & 2345 \\ 1984 & 641 & 3175 \\ 1985 & 714 & 3486 \\ 1986 & 953 & 4448 \\ 1987 & 1082 & 4015 \\ 1988 & 1053 & 4001 \\ 1989 & 1091 & 3412\end{array}$

* Merger and acquisition data has been borrowed from

Marfel (1988), and Khemani (1991).

Analytical Studies Branch - Research Paper Series - 15 - $\quad$ Statistics Canada No. 11F0019MPE No. 111 


\section{References}

Auerbach, Alan J. (1985). "Real Determinants of Corporate Leverage" in Corporate Capital Structure in the United States, ed. B.M. Friedman, University of Chicago Press.

Auerbach, Alan J. and Joel Smelrod (1997). "The Economic Effects of the Tax Reform Act of 1986", Journal of Economic Literature, vol. 35, June.

Bank of Canada (1982). Bank of Canada Review, December, Bank of Canada, Ottawa.

Baribeau, Mark B. (1989). "Leverage Risk in the Non-financial Corporate Sector", Business Economics, July.

Bartholdy, Jan, Gordon Fisher and Jack Mintz (1989). "An Empirical Study of the Impact of Corporate Taxation on the Debt Policy of Canadian Firms", Queen's Discussion Paper no. 742 .

Bauser, Randall (1990). "The Contributions to economics of Douglas Vickers", Journal of Post-Keynesian Economics, vol.12, no.2.

Bernanke, Ben S. (1993). "Credit in the Macroeconomy", Federal Reserve Bank of New York Quarterly Review, Spring.

Bernanke, Ben S. and John Y. Campbell (1988). "Is There a Corporate Debt Crisis?", Brookings Papers on Economic Activity, 1.

Borio, C.E.V. (1990). "Leverage and Finance of Non-financial Companies: An International Perspective”, Bank for International Settlements, Economic Paper no.27, May.

Calomiris, Charles W., Orphanides, Athanasios and Steven A. Sharpe (1994). "Leverage as a State Variable for Employment, Inventory Accumulation and Fixed Investment", NBER Working Paper no. 4800, July.

Cantor, Richard (1990). "A Panel Study of the Effects of Leverage on Investment and Employment”, Federal Reserve Bank of New York Research Paper no. 9011, May.

Chaplinsky, S. and G. Neihaus (1993). "Do Inside Ownership and Leverage Share Common Determinants?", Quarterly Journal of Business and Economics, vol. 32.

Davis, E.P. (1987). "Rising Sectoral Debt/Income Ratios: A Cause for Concern?” , Bank for International Settlements, Economic Paper no.20, June.

Furstenberg, George M. and Burton G. Malkiel (1977). "Financial Analysis in an Inflationary Environment”, Journal of Finance, vol.32, no.2, May. 
Harris, Milton and Artur Raviv (1991). "The Theory of Capital Structure", Journal of Finance, vol.34, no.1, March.

Jensen, Michael C. and William H. Meckling (1976). "Theory of the Firm: Managerial Behaviour, Agency Costs, and Capital Structure", Journal of Financial Economics, vol. 3 , October.

Khemani, R.S. (1991). "Recent Trends in Merger and Acquisition Activity in Canada and Selected Countries", in Corporate Globalization through Mergers and Acquisitions, ed. Leonard Waverman, University of Calgary Press.

Kregel, J.A. (1990). "Operational and financial leverage, the firm, and the cycle: reflections on Vickers' money capital constraint", Journal of Post-Keynesian Economics, vol.12, no.2.

Long, M.S. and I.B. Malitz (1985). "Investment Patterns and Financial Leverage" in Corporate Capital Structure in the United States, ed. B.M. Friedman, University of Chicago Press.

McDonald, Robert L. (1983). "Government Debt and Private Leverage: An extension of the Miller theorem”, Journal of Public Economics, vol. 22.

Mackie-Mason, J.K. (1990). “Do Taxes Affect Corporate Financing Decisions?”, Journal of Finance, vol. 45.

Marfels, Christian (1988). "Aggregate Concentration in International Perspective: Canada, Federal Republic of Germany, Japan and the United States" in Mergers, Corporate Concentration and Power in Canada, eds. R.S. Khemani, D.M. Shapiro, and W.T. Stanbury, The Institute for Research on Public Policy.

Masulis, Ronald W. (1988). The Debt/Equity Choice, Ballinger Publishing Company, Cambridge, Mass.

Mintz, Jack M. (1987). “Alternative Views of the Corporate Tax: A Reassessment of the Carter Report Twenty Years Later”, Queen's University Discussion Paper no.683, May.

Pruitt, Stephen W. and Lawrence J. Gitman (1991). "The Interaction between the Investment, Financing and Dividend Decisions of Major U.S. Firms", Financial Review, vol.26, no.3, August.

Remolana, Eli M., Robert N. McCauley, Judith Ruud, and Franco Iacono (1993). “Corporate Refinancing in the 1990s", Federal Reserve Bank of New York Quarterly Review, Winter.

Sharpe, Steven A. (1994). "Financial Market Imperfections, Firm Leverage and the Cyclicality of Employment", American Economic Review, vol.84, no.4, September. 
Shoven, John B. and John Whalley, eds. (1992) Canada-U.S. Tax Comparisons, University of Chicago Press.

Shum, Pauline M. (1996). "Taxes and Corporate Debt Policy in Canada: An Empirical Investigation”, Canadian Journal of Economics, vol. 29, no.3, August.

Taggart, Robert A. (1985). "Secular Patterns in the Financing of U.S. Corporations" in Corporate Capital Structures in the United States, ed. Benjamin M. Friedman, University of Chicago Press.

Titman, S. and R. Wessels (1988). "The Determinants of Capital Structure Choice", Journal of Finance, vol. 43.

Trezevant, R. (1992). "Debt Financing and Tax Status: Tests of the Substitution Effects and the Tax Exhaustion Hypothesis Using Firms' Response to the Economic Recovery Act of 1981", Journal of Finance, vol.47. 